\title{
İngilizce Derslerinde Anadil Kulllanımı Üzerine Bir Araştırma (Malatya İli Örneği)
}

\section{Dr. Öğr. Üyesi Münir Şahin ${ }^{1 *}$ Uzman Sosyolog Tuğba Şahin ${ }^{2}$}

Geliș tarihi: 01.10.2019

Kabul tarihi: 06.11.2019

\section{Atuf bilgisi:}

IBAD Sosyal Bilimler Dergisi

Say: $5 \quad$ Sayfa:379-396

Yıl: 2019 Dönem: Güz

This article was checked by iThenticate. Similarity Index 6\%

${ }^{1}$ Tokat Gaziosmanpaşa Üniversitesi, Sosyal ve Beşeri Bilimler Fakültesi, Türkiye, $\quad$ munir.sahin@gop.edu.tr ORCID ID 0000-0001-5722-496X

${ }^{2}$ Malatya Denetimli Serbestlik Şube Müdürlügü, Türkiye, tugbaorhan@adalet.gov.tr ORCID ID 0000-0001-9786-0928

* Sorumlu yazar
ÖZ

$\mathrm{Bu}$ çalışmada İngilizce derslerinde anadil kullanımına ilişkin İngilizce öğretmenlerinin görüşlerini belirlemek amaçlanmıștır. Yabancı dil öğretiminde anadil kullanımı çok sayıda çalışmanın yapıldığı ve çoğu kez birbirinden farklı görüşlerin ileri sürüldüğü tartışmalı bir konu olarak günümüze gelmiştir. Öğretimin ana paydaşlarından olan öğretmenlerin konuya ilişkin görüşleri hem öğretimin doğrudan içinde olmalarından hem de yabancı dil öğrenme deneyimleri nedeniyle önemli görülmüştür. Öğretmenlerin önemli bir çoğunluğu $(\% 61,7)$ şaşırtıcı bir şekilde anadilin İngilizce sınıflarında kullanılması gerektiği yönünde görüş bildirmișlerdir. Anadilin ne zaman kullanılması gerektiği konusunda ise katılımcıların yarısı özellikle dilbilgisi konularının öğretiminde anadilden faydalanmak gerektiği yönünde görüş bildirmişlerdir. Anadilin kullanılmaması gerektiği durumlar için ise ilk sırada $(\% 23,5)$ konuşma ve dinleme aktiviteleri gelmiş̧ir. İkinci sırada $(\% 17,6)$ görüş bildirenler ise öğrenciler anlamasalar bile anadil hiçbir zaman kullanılmamalı yönünde görüş bildirmişlerdir. İngilizce öğretmenlerinin literatür ile benzer görüşlere sahip oldukları, ortak bir dile sahip olmanın avantajlarından faydalanmak gerektiği yönünde çoğunluğun görüş belirttiği görülmüştür.

Anahtar Kelimeler: Anadil kullanımı, Yabancı dil öğretimi, Öğretmen görüşleri, Dil ögretimi. 


\section{A Research on the Use of Mother Tongue in English Language Classrooms (Example of Malatya Province)}

\section{Assist. Prof. Dr. Münir Şahin ${ }^{1^{*}}$ \\ Expert Sociologist Tuğba Şahin²}

First received: 01.10.2019

Accepted: 06.11.2019

\section{Citation:}

IBAD Journal of Social Sciences

Issue: 5 Pages: 379-396

Year: 2019 Session: Fall

This article was checked by iThenticate. Similartiy Index $6 \%$

1 Tokat Gaziosmanpaşa Üniversitesi, Sosyal ve Beșeri Bilimler Fakültesi, Türkiye, $\quad$ munir.sahin@gop.edu.tr ORCID ID 0000-0001-5722-496X

${ }^{2}$ Malatya Denetimli Serbestlik Şube Müdürlüğ̈̈, Türkiye, tugbaorhan@adalet.gov.tr ORCID ID 0000-0001-9786-0928

* Corresponding Author

\begin{abstract}
This study has aimed to examine the opinions of English language teachers about the use of mother tongue in foreign language classes. The use of mother tongue in teaching a foreign language has become a controversial topic for ages, and different opinions have been put forward. As main shareholders of education, the opinions of English language teachers about the use of mother tongue in language classes have been accepted important as they are both directly in teaching activities and have the experience of learning a foreign language. Surprisingly, an important number of the English language teachers $(\% 61,7)$ stated that mother tongue should be used in foreign language classes. Half of the participants stated that mother tongue should be used especially while giving grammar rules. About when not to use mother tongue, $\% 23$ percent of the participants stated that during the speaking and listening activities mother tongue should not be used. Some of the participants $(\% 17,6)$ stated that mother tongue never be used even when they did not understand anything. English language teachers that participated to the study stated similar opinions with the literature that the advantages of speaking the same mother tongue with the students should be used in English language teaching.
\end{abstract}

Keywords: Using Mother Tongue, English language teaching, Teachers' opinions, Language teaching.. 


\section{GİRIŞ}

Yabancı dil eğitimi dünyada birçok ülkenin milyonlarca dolar harcadığı ve önemsediği önemli eğitim alanıdır. Dil eğitimi gerek iş bulmak gerekse de küçülen küresel dünya bilgi ve teknoloji kullanımından rahat seyahat edebilmeye kadar birçok sorunun çözümünde anahtar rol oynamaktadır. Günümüzde "Linqua Franca" yani ortak dil olarak nitelendirebileceğimiz İngilizcenin öğrenilmesi ve öğretimi süreçleri bu nedenle daha da önemli görülmektedir. Bu nedenle İngilizce öğretiminde yeni trend ve arayışlara her geçen gün yenileri eklenmektedir. İngilizce öğretiminde çözülmemiş bir çok sorundan bir tanesi de dil sınıflarında anadil kullanımıdır. Yabancı dil öğretiminde öğretmenlerin yabancı dille birlikte anadili kullanmaları "dil değiştirme" olarak ifade edilmektedir. Yabancı dil öğretmenlerinin sınıflarında ne zaman, ne kadar anadili kullandıkları veya kullanmaları gerektiği araştırmacıların, dil bilimci ve yabancı dil öğretmenlerinin ağırlıklı olarak tartıştıkları konulardan birisidir.

Yabancı dil öğretiminde anadil (L1) kullanımına ilişkin tartışmalar en az yabancı dil öğretimi tarihi kadar eskidir (Kelly, 1969). Yabancı dil derslerinde anadilin kullanılması veya dil değiştirme (code-switching) bir dili kullanırken başka bir dile geçiş yapma olarak tanımlanmıştır (Richards ve Schmidt, 2002, s. 81). Neil (1997) yaptığı çalışmada öğretmenlerin hedef dili \%97.5 ve \%33.1 arasında değișen oranlarda kullandıklarını bulmuştur. Ancak çalışmada kullanılan örneklemin seçiminde kullanılan kriterler ve konuşma süresi açık değildir (Akt. Macaro, 2009, s. 535). Benzer bir çalışmayı yapan Wing (1980) hedef dil kullanım oranını \%70 olarak ifade etmiştir. Wing'in de bu oranın bütün ders süresi için mi yoksa toplam ders süresinin bir kısmı için mi kullandığı açık değildir (Akt. Macaro, 2009, s. 535). Al-balawi (2016, s. 58) öğretmenlerin \%80 oranında çok fazla anadili kullandıklarını, ikinci yabancı dil olan İngilizceyi çok nadiren kullandıklarını belirlemiştir. Polia ve Duff (Akt. Edstrom, 2006, s. 13) ise çoğu yabancı dil öğretmenlerinin anadili ve ikinci dili ne kadar ve niçin kullandıklarının farkında olmadıklarını belirmiştir.

Anadil kullanımına ilişkin dilbilimcileri ve araştırmacıların tutumları farklılık göstermektedir. Bazı araştırmacılar (Kahraman, 2009; Macaro, 2009; Paker ve Karaağaç, 2015; Schweers, 1999; Tang, 2002) anadil kullanımını kaçınılmaz olarak değerlendirirken, anadil kullanımının hedef dildeki becerilerin gelişmesini engelleyebileceğini savunanlarda (Kayaoğlu, Öztürk ve Dağ Akbaş, 2010; Krashen, 1982; Sarıçoban, 2010; Turnbull, 2001) bulunmaktadır. Ancak dil öğretiminde anadilin ne kadar kullanılmas1 gerektiğine ilişkin geliştirilmiş bir formül bulunmamaktadır. Schweers (1999, s. 7) öğretmenlerin anadili kullanmaları gerektiği noktasında onları cesaretlendirerek anadil kullanımı güven duygusunu geliştireceğini ve öğrencilerin deneyimlerini canlı tutacağını ifade etmiştir.

İngilizce dil sınıfında anadilin kullanılmasının bazı avantajları bulunmaktadır. Anadil kullanımı öğrenen heyecanını düşürür (Auerbach, 1993; Şavlı ve Kalafat, 2014) daha rahat öğrenme ortamı oluşturur (Burden, 2000; Philips, 1993, akt. Al Hinai, 2011). Öğrencilerin kendi kültürel birikimlerini sınıfa getirmeleri anlamına gelir (Prodromou, 2002, akt. Al Hinai, 2011). Öğrencilerin anlayıp anlamadıklarını kontrol etmeyi kolaylaştırır (Holthouse, 2006; Atkinson, 1987). Soyut kelimelerin anlamlarını açıklamayı kolaylaştırır, anadil ile yabancı dil arasındaki dilbilgisi ve telaffuz farklılıklarını göstermeye yardımcı olur (Buckmaster, 2000; Cole, 1988). Anadilin kullanılması stressiz bir ortam oluşturmaya yardım eder. Yabancı dil öğrenirken anadilin kullanılması öğrencileri dil öğrenme yorgunluğundan kurtarır. Anadil daha otantik ve zengin metinler kullanmayı sağlar. Anadil kullanımı sınıf yönetimini kolaylaştırır. Anadilde bilinenin öğrenilen dille bağlantısının kurulması öğrenmeyi kolaylaştırır (Butzkamm, 2003).

Anadil kullanımını destekleyemeyen görüşler de bulunmaktadır. Anlaşılabilir girdi sağlamanın dil öğrenmede çok önemli olduğunu savunan Krashen ve Terrel (1983), anadil kullanımının ikinci dili kullanmayı engelleyebileceğini, öğrencileri motive etmeyeceği gibi onların cesaretini de kırabileceğini savunmuştur. Krashen ve Terrel'e göre anadilin kullanılmasının yasaklanması gerekebilir. Macdonald (1993) ise dil öğretiminde sadece hedef dilin kullanılması bilinçli ve bilinçsiz öğrenmeyi ve iletişimi geliştirir. Öğretmenler tıkandıklarında resim, gösterim gibi görsellerden yararlanmalılar ancak anadili kullanmamalılar. Halliwell ve Jones'a (1993) göre hem konuşmada hem de konuşulanın anlaşılmasında hedef dilin kullanılması bir strateji olarak kelime ve yapıların tam anlamlarını bilmeseler bile ögrencilerin mesajı anlamalarına yardımcı olacaktır. Sharma (2006, s. 80) ana dil kullanımına daha sert 
bir şekilde karşı çıkar ve öğrenciler ne kadar fazla hedef dile maruz kalırlarsa o kadar çabuk dili ögrenirler. Hedef dili duydukça ve kullandıkça o dille düşünmeye başlayacaklar ve o dili kullanmanın öğrenmek için tek yol olduğunu içselleştireceklerdir.

Yabancı dil öğretiminde anadilin kullanılmaması gerektiği yönünde deliller bulunmamasına rağmen, bazı ulusal müfredat programları ana dil kullanımı konusunda oldukça iddialı olabilmekteler. Bazı ulusal programlar yabancı dil eğitiminde anadilin kullanılmasının ikinci dil edinimine ve öğrenmeye ket vurduğu veya hedef dille ilgili yanlış mesajlar oluşturduğunu ileri sürerek bütünüyle yasaklanmasını önermektedir. Department of Education and Science (1990, s. 58) sınıf içi neredeyse bütün konuşmalarda yabancı dilin doğal olarak kullanılmasının modern bir dil sınıfının işareti olduğunu belirtmiştir. İngiltere ve Galler'de Ulusal Modern Dilleler Müfredat Programı, öğretilen yabancı dilin öğretim dili olarak kullanılması gerektiğini belirtmektedir (Department of Education and Sciences, 1988, s. 12). Bunlara ek olarak, İngiltere Eğitim Standartları Ofisi (OFSTED) müfettiş kılavuzunda dil öğretiminin bütün alanlarında yabancı dil öğretmenlerinin hedef dili kullanmada ısrarlı olmaları gerektiğini, hedef dil kullanımının standartları yükselteceğini belirtmektedir (OFSTED, 1993, s. 37).

Ancak Butzkamm (2003) yabanc1 dil eğitiminde, özellikle İngilizcenin öğretiminde anadillerini bilmedikleri ülkelerde kendi dilini öğretmek durumunda kalan İngiliz veya Amerikalı tek dilli öğretmenlerin anadilin kullanılmasını yasaklayıcı ve küçümseyici bir tavır içine girdiklerini ifade etmektedir. Çok sayıda Anglo-Amerikan genç dünyanın dört bir tarafına yayılarak İngilizce öğretip geçimlerini sağlamaktalar. Bu kişilerin bulundukları ülkelerin kültürleriyle veya dilleriyle herhangi bir yakınlığı bulunmadığ 1 gibi, kendileriyle birlikte getirmiş oldukları tek dilde yazılmış kitapları kullanarak İngilizce öğretmekteler (Butzkamm, 2003, s. 30). Butzkamm’a (2003, s. 31) göre düşünmeyi, iletişim kurmayı, dilbilgisini öğrenmeyi sağlayan anadilimi sadece kendi dilbilgisinin kapılarını değil aynı zamanda evrensel dilbilgisi kurallarının da kapısını açma potansiyeline sahiptir. Bu nedenle anadilimiz ikinci dil ortamına getirdiğimiz en önemli değerimizdir.

Larsen-Freeman (2000, ss. 101-102) ve Schweers (1999, s. 7) gibi bazı araştırmacılar öğrencinin kendini güvende hissetmesi, iyi bilinenle bilinmeyen arasında köprü oluşturması, hedef dildeki kavramların anlamlarının anlaşılır kılınması için anadilin kullanılabileceğini belirtmişlerdir. Gomathi ve Kiruthika (2013, s. 24) da gümünüzde daha fazla anadilin kullanılması yönünde bir kaymanın olduğunun ifade etmiş, daha da ileriye giderek anadili kullanan öğretmenlerin kullanmayanlara göre daha başarılı olduklarını iddia etmiştir. Carson ve Kashihara (2012, s. 41) bu iddiayı daha da ileri götürerek Japonya gibi anadilin baskın olduğu ülkelerde tek dilde yabancı dil eğitiminin yapılmasının ölümcül ve gereksiz olduğunu bertmişlerdir. Macaro (2009, s. 544) yabancı dil öğretiminde hedef dil kullanımının artırılmasının öğrenmeyi geliştireceği sonucunu iddia etmekten uzak olduklarını, yaptığı çalışmanın böyle bir sonuç doğurmadığını ifade etmiştir. Sipra (2007) iki dilli yabancı dil öğretmenlerinin tek dilli yabanc1 dil öğretmenlerine göre daha fazla öğrenmeye yardımc1 oldukları belirtse bile, öğretmenlerin öğrencileri ikinci dilin kullanılması konusunda önemli role sahip olduklarını, materyallerini öğrencilerin yeterlilik düzeylerine uygun hazırlayarak onları daha fazla ikinci dil kullanımı konusunda teşvik etmeleri gerektiğini belirtmiştir.

\section{Anadil Kullanımı ve Dil Öğretim Yöntemleri}

Dil öğretim yöntemlerinin anadil kullanımına ilişkin bakış açıları farklılık göstermektedir. Dilbilgisi çeviri yöntemi (grammar-translation method) gibi bazı dil öğretim yöntemleri anadili dil öğretiminde önemli bir araç kabul etmektedir. En eski dil öğretim yöntemlerinden birisi olan dilbilgisi çeviri yönteminde öğrencilerin bir dilden diğerine çeviri yapmaları, anadildeki kelimenin hedef dildeki karşılığının ezberlenmesi ve yönergelerin anadilde verilmesi gerekir (Larsen-Freeman, 2000, s. 17-18). Hedef dilin kullanılmasına odaklanmayan dilbilgisi çeviri yönetimin aksine, doğrudan dil öğretim yöntemi anadilin kullanılmasını tamamen yasaklamaktadır (Diller, akt. Larsen-Freeman, 2000, s. 23). Anadilin kullanılmasını yasaklayan anlayışın tarihi yirminci yüzyılına başlarında gelişen doğrudan yöntemine (direct method) kadar gitmektedir (Harbord, 1992). İngilizce derslerinde doğrudan gösterim, görsel materyaller kullanılarak, anadil kullanımına yer vermeden anlamın iletilmesi amaçlanmaktadır. Çocukların anadil edinimleri ile yetişkinlerde ikinci dil öğrenmeye arasındaki benzerliklerden yola çıkarak anadilin ikinci dil öğrenmeyi zorlaştırdığı, karışıklı̆ga neden olduğu gerekçesiyle resimlerin, mimiklerin çeviri yerine kullanılması gerektiği benimsenmiştir (Al-nofaie, 2010, s. 65). Richards ve 
Rodgers (2005, s. 13) doğrudan dil öğretim yöntemine öğretmenlerin anadilde kısa bir çeviri ile ifade edilebilecek kavramlar yerine çok uzun anlatımlar gerektirmesinden dolayı karşı çıktıklarını ve Avrupa'da devlet okullarından yasaklandığını belirtmiştir.

İletişimsel Dil Öğretimi (Communicative Language Teaching), Görev Temelli Dil Öğretimi (TaskBased Language Learning) ve Doğal Yaklaşım (Natural Approach) gibi bazı öğretim metotları anadil kullanımı tamamen yasaklamasalar da kısıtlarlar. Ancak doğrudan yöntemi (Direct Method), Dil İşitim Yöntemi (Audio-Lingual Method) gibi bazı dil öğretim yöntemleri anadil kullanımını yasaklamaktadır. Dil İşitim Yöntemine göre anadildeki alışkanlıklar öğrencilerin İngilizce'yi anlamalarını zorlaştırmaktadır. Anadil ve ikinci dil farklı sistemlerden oluşmaktadır bu yüzden sadece ikinci dilin sınıfta kullanılması gerekir (Larsen-Freeman, 2000). Dil öğrenimini davranış şekillendirme olarak tanımlayan davranışçı psikolojiden temellerini alan Dil İşitim Yönteminin yerini alan Bilişsel Yaklaşım (Cognitive Approach) dil öğrenmeyi bir dizi kuralın edinilmesi olarak tanımlamıştır. Bilişsel ve Dil İşitim Yöntemlerinden sonra dil öğretim yöntemlerinde büyük bir çeşitlilik ortaya çıkmıştır (Koucka, 2007).

Sessiz Yöntem (Silent Way) yönerge verme, telaffuza yardımcı olma ve geri-dönüt vermek dışında anadil kullanımını kısıtlarken, Öneri Yöntemi (Suggestopedia) anadil kullanımında daha serbesttir. Bu dil öğretim yönetiminde anlamı açıklamak için anadile çeviri yapılması veya öğretmenin ne zaman ihtiyaç duyarsa anadili kullanabilmesi mümkündür. Topluluk Odaklı Dil Ögreniminde (Community Language Learning) mümkün olduğunca kelimelerin anadildeki karş1lıklarının verilebilir, hatta İngilizce diyalogların yerini anadildeki diyaloglar alabilir. Bütüncül Fiziksel Tepki Yöntemi (Total Physical Response) ise anadil kullanımına sadece konuya giriş yapmak için izin verir. Anlamın vücut hareketleriyle açıklanması gerekir (Larsen-Freeman, 1986), emir kipi kullanılarak öğrencilerden fiziksel tepki göstermeleri beklenir (Lasagabaster, 2013, s. 2). Yabancı dil öğretiminden Eşzamanlı Yöntem (Concurrent Method) anadilin ve ikinci dilin dengeli kullanılmasını önerir (Faltis, 1990). İki Dilli Yöntem (Bilingual Method) (Dodson, 1967) ve Karşılıklı Dil Öğretim Yöntemi (Reciprocal Language Teaching Method) (Hawkins, 1987) dil yeterliliğine sahip öğrenenler yetiştirmeyi amaçlar ve anadilin sınıflarda öğrencilerin tarafından kolaylıkla kullanılabileceğini fikrini savunurlar (Al-nofaie, 2010, s. 68).

Günümüzde kullanılan İletişimsel Dil Öğretim Yöntemi (Communicative Language Teaching Method) Richards ve Rogers'ın (2005) da ifade ettiği gibi dil öğrenmede odak noktasını gramer gibi dil öğelerinden çok dile ve dili kullanmaya odaklanılması gerektiğini öne çıkaran yöntemdir. İletişim becerisinin öğrencilerin aktif olarak anlamlı iletişim ortamlarında dili kullanmalarıyla gelişeceği savunmaktadır. Dil bir dizi kural setinden daha fazlasıdır. Dil bilgisi kurallarını ve bu kuralların gerektiğinde uygun bir şekilde kullanılmasının birbirinden ayrılması gerekir (Nunan, 1989, s. 12). Anadil İletişimsel Dil Ögretimi Yönteminde makul bir şekilde kullanılabilir. Ancak, amaç hedef dili kullanarak iletişim kurmak olduğundan sadece diyalog oluştururken değil, hedef dilin iletişimde bir araç olduğunun farkına varmaları için ödev verirken, aktivitelerin nasıl yapılacağını anlatırken de İngilizcenin kullanılmasına özen gösterilmesi gerekir (Larsen-Freeman, 2000, s. 132).

Yııllar boyunca en iyi şekilde yabancı dil öğretmeye ilişkin görüşler Dilbilgisi Çeviri, ezberleme ve tekrarlar yapmadan gerçek hayata uygun ortamlarda dilin kullanılmasına kaymıştır. İletişim becerisini artırmak için belki de günümüzde en fazla tercih edilen yöntemlerden birisi İletişimsel Dil Öğretim Yöntemidir. Moss (2005, s. 3) İletişimsel Dil Öğretim Yönteminin temelini öğrenenlerin dili otantik diyaloglar içinde kullanma ihtiyaçları oluşturduğun ifade etmiş̧ir. Gerçek dil ortamında doğru gramer kuralını veya kelimeyi kullanmaktan çok anlaşılır olmak daha fazla önem taşımaktadır. Dil anlaşılır bir şekilde kullanabilmek ise öğrencilerin etkileşimli dil ortamında dili kullanma olanaklarına bağlıdır. Brown ve Ellis'e göre öğrencilere etkileşim olanakları sağlamak öğretmenin görevidir (Akt. Moss, 2005, s. 5).

\section{Yabancı Dil Öğretmenleri Niçin Anadili Kullanmak İstiyorlar?}

Öğretmenler çeşitli sebeplerden dolayı anadili kullanmayı tercih edebilmekteler. Bu sebeplerden birincisi dil öğretiminde anadilin ve ikinci dilin öğretim ortamını oluşturmada önemli role sahip olması ve gerekli olduğunda öğretmenlerin anadile dönmek istemeleridir. İkincisi, anadilin kullanılmasının rahat ve olumlu bir öğrenme ortamı oluşturmasıdır. Öğretmenler anadili karışık görevleri, yeni kelime ve ifadeleri 
anlatırken kullanabilirler. Üçüncü önemli sebep ise anadile geçiş yapabilmek öğrencilerin kendi duygu ve düşüncelerini daha rahat ifade edebilmelerini sağlamaktadır. Öğrencilerin yabancı dili kullanarak iletişim kurmada yetersiz oldukları durumlarda anadil onların iletişim halinde kalmalarını sağlamaktadır (Atkinson, 1987; Cook, 1999; Harbord, 1992; Storch ve Wigglesworth, 2003). Littlewoods (1981) ise anadilin sınıf yönetimi ve öğretimde kullanılabilir olmasına rağmen ikinci dilin kullanılması yönünde öğrencilerin teşvik edilmesini önermiştir.

Araştırmacılar öğretmenlerin yabancı dil sınıflarında anadil kullanmalarını çoğunlukla öğrencilerin hatalarını düzeltme, dilbilgisi kurallarını anlatma, yönerge verme (Atkinson, 1987; Cook, 2001; Edstrom, 2006; Gulzar, 2010; Macaro, 2009; Patel ve Jain, 2008; Tang, 2002), öğrencileri motive etme (Duff ve Polio, 1990), sınıf içi disiplini devam ettirme (Nation, 2003; Ramos, 2005), öğrencilerin konuyu anlayıp anlamadıklarını kontrol etme (Gulzar, 2010; Holthouse, 2006; Moghadam, Samad ve Shahraki, 2012; Sharma, 2006; Turnbul, 2001), daha hızlı ve kolay olduğu için kelimelerin anlamlarını verme, açıklama yapma (Atkinson, 1987; Çelik, 2003; Gomathi ve Kiruthika, 2013, s. 24; Şenel, 2010) amaciyla yaptıklarını ifade etmişlerdir. Örneğin Turnbull'e (2001, s. 535) göre zor bir dilbilgisi kuralının, kavram veya kelimenin anlaşılıp anlaşılmadığını kontrol etmek için anadile kısa anlık dönüşler yapılabilir.

Nation (2003) ikinci dil veya yabancı dilin sınıf ortamında aşırı kullanılması özellikle utangaç veya ikinci dilde iyi olmayan öğrenciler için utangaçlı̆ga neden olabileceğini vurgulamıştır. Samadi (2011, s. 17) öğretmenlerin anadili daha az stresli bir sınıf ortamı oluşturmak, dilbilgisi kurallarını anlatmak, kelimelerin çevirisini yapmak, sınıf yönetimi ve yönerge vermek amacıyla kullandıklarını vurgulamıştır. Samadi ayrıca kendine güven düzeyi düşük olan, korkmuş, gönülsüz, heyecanlı öğrencileri teşvik etmek amacıyla anadil kullanılabilir. Anadil öğrencileri yabancı dil sınıfında güven sağlayacaktır. Harmbord'a (1992, s. 352) göre anadil kullanımı öğretmen-öğrenci iletişimini kolaylaştırır. Öğretme ve öğrenci arasındaki dostluğu geliştirir ve öğrenmeyi kolaylaştırır.

Atkinson (1987, s. 7) anadilin kullanılmasının kelime ve ifadelerin anlamlarını destekleyeceğini, özellikle iki dil arasındaki anlam boşluğunu tamamlamada faydalı olacağını ifade etmiştir. Atkinson (1987, ss. 243-244) ve Holthouse'a (2006, ss. 32-35) göre öğretmenler öğrenciler arasında dayanışma gerektiren durumlarda, anlamı kontrol etme, düşük düzeylerde yönerge vermede, öğrencilerin duygularını anlama amaciyla ve sınıf öğretim yöntemine ilişkin tartışmalarda anadili kullanabilirler. Kadın İngilizce öğretmenleriyle yaptığı çalışmada Al-balawi (2016) ve Al-nofaie (2010) ana dilin kullanılmasına karşı öğretmenlerin olumlu tutum içinde olduklarını ve öğretmenlerin öğrenmeyi kolaylaştırmak ve sınıf içinde öğrenme deneyimini geliştirmek gibi nedenlerden anadili bir pedagojik araç olarak kullandıklarını ortaya koymuşlardır. Al-nofaie (2010) çoğu öğretmenin anadili dilbilgisi kurallarının ve kelimelerin açıklamasında kullandıklarını gözlemlemiştir. Prabhu (1987) ise öğrencilerin ögretmenleriyle özel olarak görüştüklerinde veya bireysel ödevler yaptıklarında daha fazla anadillerini kullandıklarını belirtmiştir (Atk, Al-nofaie, 2010).

Dört İngilizce öğretmeniyle yaptığı çalışmada Sharma (2006) öğretmenlerin zor kelimelerin anlamlarını açıklamak, dil bilgisi kurallarını anlatmak, öğretmen ve öğrenci arasında daha yakın ilişkiler geliştirmek için öğretmenlerin anadili kullandıklarını belirlemiştir. Anadilin öğrencileri ikinci dili daha etkili öğrenmelerini sağladığını, anadile çevirilerin kolaylık ve zaman tasarrufu sağladığını belirtmiştir. Sharma, öğrencilerle sohbet ederken, yönerge verirken, geri dönüt vermede, hataların düzeltilmesinde ve ögrencilerin anlayıp alamadıklarını kontrol etmede anadilin kullanılmasını önermektedir. Duff (1989) ise anadile çevirinin öğrencilerin dili esnek, doğru ve açık kullanmalarını sağladığını ifade etmiştir. Çeviri yapmak öğrencilerin doğru kelimeyi bulmak için araştırma yapmaları sağlamaktadır. Perkin (1985, akt. Soleimani ve Heidarikia, 2017, s. 2) çeviri ile iki dilin dilbilgisi yapılarını karşıllaştırmanın öğrencilerde dil bilimsel farkındalık oluşturduğunu ifade etmiş̧ir. Çeviri her yerde neden sınıfta olmasın (Duff, 1989, akt. Soleimani ve Heidarikia, 2017, s. 2). Soleimani ve Heidarikia'ya (2017) göre çevirinin psikolojik faydaları göz ardı edilmektedir. Çeviri dil öğretiminde önemli bir öğretim stratejisi olarak kullanılabilir.

Faltis (1990) ise anadilin özellikle yeni kavramların anlatılmas1, önceki ders konusunun tekrar1, öğrencilerin dikkatini konuya çekmek ve öğrencilere olumlu dönüt ve övgüde bulunmak gibi dört önemli alanda anadilin kullanıldığını belirlemiştir. Yeni Eşzamanlı Yöntem olarak adlandırılan dil öğretim yönteminde Faltis, öğretmenlerin anadil ile ikinci dili dengeli bir şekilde kullanmaları gerektiğini belirtmiştir. Harbord (1992) ana dili öğretmen ve öğrenci arasında doğal bir iletişim aracı olarak 
tanımlarken dilbilgisi anlatımında ana dilin kullanılmasına karşıdır. Stern (1992) ise ana dil ve hedef dilin karşılaştırılarak aradaki benzerlik ve farklılıkların öğrenmeyi kolaylaştıracak şekilde kullanılabileceğini belirtmiştir. Sarıçoban (2010) öğretmenlerin zor kavramları, yeni kelimeleri anlatmak ve öğrencilerin anlayıp anlamadıklarını kontrol etmek için anadili kullandıklarını belirlemiştir. Şavlı ve Kalafat (2014, s. 1380) anadilin kullanıldığı sınıflarda öğrencilerin "bilinmeyen konu ve kavramların öğrenilmesinin ve anlaşılmasının daha da kolaylaştığını" vurguladıklarını, öğrencilerin "motivasyonunun ve özgüveninin arttığını, o derse karşı önyargılı davranmayıp derste rahat olduklarını" belirtmiştir. Ayrıca anadil kullanımının derse karşı olan ilgiyi artırıp öğrencilerin rahat hissetmelerini sağladığını belirtmiştir. Macaro (2009) kelime öğrenme ile anadilin kullanılması arasındaki ilişkiyi incelemiş ve anadilin kullanılmasının kelime öğrenmeyi olumlu yönde etkilediğini ortaya koymuştur.

Auerbach (1993, s. 19) ve Schweers (1999, s. 6) ikinci dilin sınıfta aşırı kullanılmasının sadece motivasyon ve morali düşürmeyeceğini, öğrencilerde reddedilme, yabancılaşma, kendi dil ve kültürünü aşağılama duygularını geliştireceğini ifade etmişlerdir. Hopkins $(1988$, s. 18) kişinin benlik algısı ile anadili arasında sıkı bir bağ bulunduğunu, anadilin kullanılmasının yasaklanmasının kişinin kimliğine karşı bir tehdit olarak hissedilebileceğini belirtmiştir. Öğretmen ve öğrencilerin yeni kelime ve kavramları anlamak için anadilin kullanılmasını isterler (Schweers, 1999, s. 9). Aucbach (1993, s. 18) anadilin kullanılabileceği durumlar olarak program hakkında ve dersle ilgili konuşmalar, not tutma, sınıf yönetimi, sahneyi oluşturma, dil analizleri yapma, dilbilgisi, kelime bilgisi, ses bilgisi ve imla kurallarının anlatımı, kültürler arası konuları tartışma, yönerge veya sufle verme, hataların anlatımı ve anlamanın değerlendirilmesini belirtmiştir. Anadile, hedef dilde başlangıç düzeyinde olan öğrenciler ileri düzeyde olanlara göre daha fazla ihtiyaç duyarlar (Carson ve Kashihara, 2012, s. 46; Şavlı ve Kalafat, 2014, s. 1380). Ancak başka bir çalışmada ileri düzeyde İngilizce seviyesine sahip olanların anadil kullanıldığı durumlarda daha iyi ilerledikleri belirtilmiştir (Ocak, Kuru ve Özcalisan, 2010, s. 69).

Paker ve Karaağaç (2015, s. 112) yabancı dil sınıfinda anadilin aşırıya kaçarak öğrencilerde bağlılık yaratmamak şartıyla kullanılabileceğini ifade etmişlerdir. Yabancı dil öğretiminde anadil kullanımını destekleyen yöntemler kadar, yabancı dil eğitiminin etkin aktörleri olan öğretmenlerin konuya ilişkin tutum ve görüşleri de önemlidir. Kayaoğlu (2012) yapmış olduğu çalışmada özellikle öğretmenlerin başlangıç düzeyinde anadil kullanımı konusunda görüş birliği içinde olduklarını ve öğretmenlerin \%96,7 gibi önemli bir çoğunluğunun anadil kullanımının ikinci dil öğrenmeyi kolaylaştırdığını ifade ettiklerini rapor etmiştir. Schweers (1999, s. 6) ise yaptığı çalışmada öğrencilerin \%88,7'sinin anadillerinin kullanılmasını istediklerini rapor etmiştir. Schweers (1999), Carson ve Kashihara (2012) göre anadil güven hissi uyandırmakta, öğrencilerin deneyimlerini doğrulamakta ve onlara kendilerini ifade etme firsatı vermektedir. Dil öğrenmenin amacı dili iletişimde kullanmak olduğundan iletişim becerisinin geliştirilmesi gerekir. İletişim becerisi dil sınıfinda hedef dili kullanmadan geliştirilemeyecektir. $\mathrm{Bu}$ anadilin bütünüyle yasaklanması anlamına gelmemelidir. Yapılan araştırmalarda da önerildiği gibi makul ve gerekli görüldüğ̈̈ miktarda anadilin kullanılmasına izin verilebilir (Koucka (2007).

Anlaşılır girdi sağlanması dil edinimi açısından önemlidir. Öğrencinin heyecan, korku, kızgınlık gibi duygularının belli bir düzeyin üzerine çıkması girdiyi engelleyecektir (Krashen (1981, ss. 51, 68). Bu nedenle öğrencilerin aktiviteleri yerine getirirken düşük düzeyde de olsa anadil kullanmaları dil öğrenimine olumlu olarak yansıyabilir. Okul öncesi öğretmenleriyle yapılan bir çalışmada anadilin kullanılmasının dil öğrenmede olumlu etkisinin olduğu görülmüştür (Mulia, 2015). Ancak gerek Krashen'ın (1981) anlaşılabilir Girdi Hitopezi (Input Hypothesis), VanPatten'in (2004) Girdi İsşem Modeli, gerekse de Long'ın (1981) Etkileşim Hipotezi (Interaction Hypothesis) ikinci dil ediniminde özellikle ikinci dilde girdinin önemli olduğu ortak noktasında birleşirler. Ancak Storch ve Wigglesworth (2003) gibi araştırmacılar sözlü iletişimi devam ettirmek ve başlatmak için anadilin kullanılabileceği ve tamamen yasaklanmasının doğru olmadığı üzerinde dururlar. Bazı araştırmacılarda (Meyer, 2008; Norman, 2008; Ocak ve ark., 2010) anadil kullanımının duygusal filtrelemeyi (affective filter) düşürmek için bir araç gibi kullanılabileceğini, öğrencilerin çoğunlukla utanma korkusuyla konuşmadıklarını ifade etmişlerdir.

İkinci Dil Öğrenme (Second Language Learning) ortamı ile Yabancı Dil Öğrenme (Foreign Language Learning) birbirinden farklıdır. İkinci Yabancı Dil öğrenme ortamında öğrencilerin sınıf içinde öğrendikleri dili pratik yapabilecekleri hedef dil ortamı mevcuttur ve öğrenciler sinıfta öğrendiklerini 
dışarda devam ettirme ve pratik yapma imkanına sahiptirler (Holthouse, 2006; Mattioli, 2004). Ancak yabancı dil öğrenme ortamında öğrencilerin böyle bir avantajı söz konusu değildir. Örneğin, Türkiye'de ögrenciler İngilizceye sadece ders gördükleri sınıf veya okul ortamında maruz kalabilmekteler ve kendi anadilleri Türkçeyi okul dışında kullanmaya devam etmekteler. Yabancı dil olarak İngilizce öğrenilirken öğrencilerin mümkün olduğu kadar fazla İngilizceye maruz kalmaları ve İngilizceyi sınıf içinde mümkün olduğu kadar fazla kullanmaları teşvik edilmelidir (Atkinson, 1987, s. 12).

Anadil kullanımının bazı dezavantajları da bulunmaktadır. Mahmutoğlu ve Kıcır, 2013, s. 55) anadilin fazla kullanılmasının ikinci dili daha az kullanmayı doğuracağını ve öğrencilerin kendilerini anadillerini bağlı hissetmelerine yol açacağını belirtmiştir. Atkinson (1987, s. 246) ise anadilin fazla kullanılması durumunda öğrencilerin çeviri yapılmadan dille ilgili hiçbir şeyi anlamadıkları hissine kapılabileceklerini, yabancı dilde kendilerini ifade edebilecekleri durumlarda bile öğrencilerin anadili kullanmayı tercih edebileceklerini, sınıf içi aktivitelerin genelinde yabancı dilin kullanılması gerektiğinin farkına varamayacaklarını belirtmiştir.

Willis (1991, s. 1) ilk derslerden itibaren öğrencilere İngilizce derslerinin İngilizce kullanılarak öğretilebileceğini, ancak öğrencilerin sınıfta kullanılan İngilizcenin önemli olduğu konusunda ikna edilmeleri gerektiğini belirtmektedir. Willis, yeni konuların her zaman gösterim ve resim gibi görseller kullanılarak anlamın anlaşılır hale getirilmesini ve öğrenciler ne zaman anadillerini kullanarak konuyla ilişkili bir şey söylerlerse, öğrencinin ifadesinin İngilizceye çevrilerek tekrar edilmesinin öğrencileri zamanla İngilizce cevap vermeyi öğreteceğini savunmaktadır. Özellikle belli bir süre İngilizce öğrenmiş gruplarda dersin İngilizce anlatılması daha kolaydır. Bütün bu iddialarına rağmen Willis öğretmenlerin anadili bazen daha ekonomik olduğu için kullanabilecekleri fikrine karşı gelmez. Willis (1991) öğretmenlerin özellikle İngilizce derslerinde yeni kelimelerin öğretiminde, yeni aktiviteler anlatılırken, öğrencilerin ne öğreneceklerini bildiklerinden emin olmak için, ders sunumundan sonra öğrencilerin anlayıp anlamadıklarını kontrol ederken, bir okuma parçasının ana fikrini tartışırken ve öğrenciler anadili kullanmak için izin aldıklarında anadil kullanmalarının daha ekonomik olabileceğini savunmuştur.

Öğrencileri İngilizce konuşmaya teşvik etmek için Harmer (2004, ss. 126-130) öğretmenlerin öğrencilerle İngilizce kullandıkları zaman veya anadillerini kullandıklarında ne hissettiklerini tartışabileceklerini önermektedir. Ayrıca öğrencilerin İngilizceyi doğru kullanmaları konusunda cesaretlendirilmeleri, anadili kullanan öğrencilerin İngilizce konuşuncaya kadar görmezden gelinmesini, öğretmenlerin çoğunlukla İngilizce konuşarak öğrencileri sürekli İngilizceyle karşılaşmalarını sağlamasını ve öğretmenlerin öğrencileri sürekli İngilizce konuşma konusunda cesaretlendirmeye devam etmelerini önermektedir. Harmer'ın bu önerileri öğrencileri İngilizce konuşmaya cesaretlendirmek için kullanılabilecek birer strateji olarak görülebilir.

Sınıf içinde daha fazla İngilizceyi kullanmak ve anadile geçişleri azalmak için Willis (1991, s. 84) öğretmenlerin basit bir dil kullanmalarını, yönerge ve anlatımlarda bulunurken mimiklerini kullanmalarını, gösterimde bulunmalarını, bazen tekrarlar yapıp, zor gibi görünen yapıları basitleştirerek farklı kelime ve yapılarla yeniden ifade etmelerini, mümkün olduğunca fazla örnek vererek her firsatta görsel materyallerden yararlanmalarını ve çeşitli aktiviteler için sınıf içi rutinler oluşturmanın faydalı olacağını savunmuştur.

Şahin, Korkmaz ve Üstüner (2018, s. 2) öğrenmeyi etkileyen çeşitli faktörlerin olduğunu ifade etmişlerdir. Fizyolojik, biyolojik, ekonomik faktörler kadar bireyin özellikleri, kullanılan yöntem ve materyaller, öğrenme ortamı yabancı dil öğreniminde de önemli faktörlerdir. Yabancı dil öğrenme ortamında öğrencilerin ve öğretmenin anadil kullanımları konusunda yapılan araştırmalar ve tartışmalar İngilizce öğretimine farklı bakış açıları kazandırmıştır. Bu çalışma da yabancı dil olarak İngilizce öğretiminde anadil Türkçe’nin kullanımı konusunda İngilizce öğretmenlerinin bakış açılarını belirmeyi amaçlamıştır. Bu amaçla:

a) İngilizce öğretmenlerinin dil sınıflarında anadil kullanımına ilişkin düşünceleri nelerdir?

b) İngilizce öğretmenleri hangi durumlarda ve özellikle hangi konuları anlatırken anadil Türkçe'yi kullanmayı tercih etmektedirler?

sorularına cevap aranmıştır. 


\section{YÖNTEM}

Bu çalışma yabancı dil olarak İngilizcenin öğretildiği dil sınıflarında Türkçenin kullanılmasına ilişkin İngilizce öğretmenlerinin görüşlerini belirlemeyi amaçlamaktadır. Araştırma olgubilim desenine uygun olarak yapılmış, nitel bir araştırmadır. Türkçenin yabancı dil olarak İngilizcenin öğretildiği sınıflarda kullanılmasına ilişkin bütüncül bir bakış açısı elde etmek (Fraenkel ve Wallen, 2006) ve bu olguya ilişkin İngilizce öğretmenlerinin görüşlerinin araştırılması amaçlanmıştır.

\section{Araştırmanın Katılımcıları}

Araştırma Malatya il sınırları içinde Milli Eğitim Bakanlığına bağlı olarak faaliyet gösteren kamu ve özel sektöre ait ilk, orta ve lise düzeyindeki okullarda görev yapan 34 İngilizce öğretmeninin katılımı ile yapılmıştır. Ölçüt örnekleme yöntemi ile en az 5 ylllık hizmet yılına sahip İngilizce öğretmenleri araştırmaya dahil edilmiştir. Üç farklı okul düzeyinden öğretmenlerle görüşülerek maksimum çeşitlilik sağlanmıştır.

Tablo 1: Katılımcı Özellikleri

\begin{tabular}{|c|c|c|c|c|c|c|c|c|}
\hline \multirow[b]{3}{*}{ Sira No } & \multirow[b]{3}{*}{ Yaş } & \multirow[b]{3}{*}{ Hiz. Yılı } & \multirow{2}{*}{\multicolumn{2}{|c|}{ Cinsiyeti }} & \multicolumn{2}{|c|}{$\begin{array}{l}\text { Çalıştığı } \\
\text { Türü }\end{array}$} & \multirow[t]{2}{*}{ Okul } & \multirow[t]{3}{*}{ Kod } \\
\hline & & & & & & & & \\
\hline & & & Kadın & Erkek & İlk & Orta & Lise & \\
\hline 1 & 35 & $10-15$ & & + & + & & & Ö1 \\
\hline 2 & 31 & $5-10$ & & + & + & & & Ö2 \\
\hline 3 & 39 & $10-15$ & + & & + & & & Ö3 \\
\hline 4 & 29 & $10-15$ & + & & + & & & Ö4 \\
\hline 5 & 28 & $5-10$ & + & & + & & & Ö5 \\
\hline 6 & 34 & $5-10$ & + & & + & & & Ö6 \\
\hline 7 & 32 & $5-10$ & + & & + & & & Ö7 \\
\hline 8 & 32 & $10-15$ & & + & & + & & Ö8 \\
\hline 9 & 30 & $5-10$ & & + & & + & & Ö9 \\
\hline 10 & 37 & $10-15$ & + & & & + & & Ö10 \\
\hline 11 & 30 & $5-10$ & + & & & + & & Ö11 \\
\hline 12 & 34 & $5-10$ & + & & & + & & Ö12 \\
\hline 13 & 31 & $5-10$ & + & & & + & & Ö13 \\
\hline 14 & 58 & $20-$ & & + & & + & & Ö14 \\
\hline 15 & 27 & $5-10$ & & + & & + & & Ö15 \\
\hline 16 & 48 & $15-20$ & + & & & & + & Ö16 \\
\hline 17 & 35 & $10-15$ & & + & & & + & Ö17 \\
\hline 18 & 31 & $5-10$ & + & & & & + & Ö18 \\
\hline 19 & 30 & $5-10$ & & + & & & + & Ö19 \\
\hline 20 & 31 & $5-10$ & + & & & & + & Ö20 \\
\hline 21 & 39 & $10-15$ & & + & & & + & Ö21 \\
\hline 22 & 35 & $10-15$ & & + & & & + & Ö22 \\
\hline 23 & 46 & $20-$ & & + & & & + & Ö23 \\
\hline 24 & 36 & $10-15$ & & + & & & + & Ö24 \\
\hline 25 & 28 & $5-10$ & + & & & & + & Ö25 \\
\hline 26 & 29 & $5-10$ & & + & & & + & Ö26 \\
\hline 27 & 30 & $5-10$ & & + & & & + & Ö27 \\
\hline 28 & 28 & $5-10$ & & + & & & + & Ö28 \\
\hline 29 & 28 & $1-5$ & & + & & & + & Ö29 \\
\hline 30 & 35 & $1-5$ & + & & & & + & Ö30 \\
\hline 31 & 34 & $1-5$ & & + & & & + & Ö31 \\
\hline 32 & 25 & $1-5$ & + & & & + & & Ö32 \\
\hline 33 & 41 & $15-20$ & + & & + & & & Ö33 \\
\hline 34 & 27 & $1-5$ & + & & & + & & Ö34 \\
\hline
\end{tabular}

Tablo 1'de görüldüğü 17'si kadın, 17'si erkek toplam 34 İngilizce öğretmeni ile görüşme yapılmıştır. Farklı okul düzeylerinde çalışan İngilizce öğretmenlerinden 8'si ilkokul, 10'u ortaokul ve 16'sı lise düzeyinde çalışmaktadır. En kıdemli yaşlı katılımcı 58 yaşında, en genç katılımcı ise 25 yaşındadır. Çalışmaya katılan öğretmenlerin çoğunluğu $(\% 98,6) \quad 5-10$ yıllık hizmet yılına sahip oldukları görülmektedir. Katılımcılardan her bir öğretmen Ö1, Ö2.... şeklinde kodlanmış ve metin içinde bu kodlar kullanılmıştır. 


\section{Veri Toplama Aracı ve Verilerin Analizi}

Fenomenolojik (Olgubilim) çalışmalarda "fenomeni deneyimleyen bireylerle gerçekleştirilen mülakatlar" (Creswell, 2013, s. 79; Simon ve Goes, 2011, s. 1) veri toplama sürecini oluşturur. Öğretmenlerin yabancı dil olarak İngilizcenin öğretildiği sınıflarda anadil Türkçenin kullanılmasına ilişkin görüşlerini belirlemek amacıyla veri elde etmek için yarı yapılandırılmış görüşme formu kullanılmıştır. Görüşme yöntemi olgubilim çalışmalarında katılımcılardan derinlemesine bilgi elde etmek için kullanılan önemli bir araçtır (Creswell, 2013, s. 162).

Alanyazın taraması doğrultusunda iki sorudan oluşan yarı yapılandırılmış görüşme formu düzenlenmiştir. Soruların konu odaklı olmasını, yeterliliğini, anlaşılır ve kapsayıcı olmasını sağlamak amaciyla Mustafa Kemal Üniversitesi, İnönü Üniversitesi ve Muş Alparslan Üniversitesinde görev yapan üç öğretim üyesinden uzman görüşü alınmıştır. Görüşmelerde nitel çalışmalarda soru sayısının az olması üzerinde öğretim üyeleri ısrar etmişlerdir. Bu nedenle sorular sadeleştirilmiş ve soru sayısı azaltılmıştır. Görüşme formunda pratik olması ve fazla zaman almaması için konuyla doğrudan ilişkili iki soru sorulmasına karar verilerek forma son şekli verilmiştir.

Formların üzerinde görüşme yapılan öğretmenlere ilişkin tanımlayıcı bilgilere yer verilmiştir. Öğretmenlerin hizmet yılı, cinsiyetleri, yaş, okul türü kişisel özelliklerini tanımlayıcı sorulara yer verilmiştir. Görüşmeden elde edilen veriler formlar üzerine araştırmacı tarafindan not tutularak kaydedilmiştir. Eksiklikleri tamamlamak ve yanlış anlaşılmaları gidermek amacıyla tutulan notlar katılımcılara okunarak teyit ettirilmiştir.

Çalışmadan elde edilen verilerin analizinde betimsel analiz tekniği kullanılmıştır. Analizler literatür 1şığında yorumlanmış ve bazı çıkarımlarda bulunulmuştur. Katılımcı görüşleri kod ve temalar altında tablolarda verilmiş, tablolarda yer alan veriler ayrıca katılımcılardan doğrudan alıntılarla desteklenmiştir.

\section{BULGULAR}

Bu bölümde alt problemlere cevap olabilecek şekilde veriler analiz edilmiş tema ve kodlar oluşturularak ayrı başlıklar altında verilmiştir.

\section{İngilizce Öğretmenlerinin Dil Sınıflarında Anadil Türkçenin Kullanımına İlişkin Düşünceleri}

İngilizce öğretmenlerine "Dil sınıflarında anadil Türkçenin kullanımı hakkında ne düşünüyorsunuz? Sizce anadil kullanılmalı mı? Niçin kullanılması gerektiğini veya kullanılmaması gerektiğini düşünüyorsunuz?" soruları sorulmuş̧tur. Katılımcıları vermiş oldukları cevaplar analiz edilmiş ve analiz sonucu Tablo 2'de verilmiştir.

Tablo 2: “İngilizce Derslerinde Anadil Kullanılmalı mı?” sorusuna verilen cevaplar

\begin{tabular}{|c|c|c|c|}
\hline Öğretmenlerin Görüşleri & Katılımeı kodu & $\mathbf{f}$ & $\%$ \\
\hline Bazen kullanılmalı. & $\begin{array}{l}\text { Ö1, Ö3, Ö4, Ö6, Ӧ7, Ö9, Ö13, Ö14, Ö18, } \\
\text { Ö19, Ö20, Ö22, Ö23, Ö26, Ö27, Ö28, Ö29, } \\
\text { Ö30, Ö31, Ö32, Ö33 }\end{array}$ & 21 & 61,7 \\
\hline Hayır, ders İngilizce anlatılmalı. & $\begin{array}{l}\text { Ö2,Ö5,Ö8,Ö10,Ö11,Ö12,Ö15,Ö16,Ö17,Ö21, } \\
\text { Ö24, Ö25, Ö34 }\end{array}$ & 13 & 38,2 \\
\hline
\end{tabular}

Tablo 2 incelendiğinde İngilizce öğretmenlerinin önemli çoğunluğunun dil derslerinde anadil kullanılması konusuna olumlu baktıkları görülmektedir. Anadil kullanılmasına karşı çıkan öğretmenler ise öğrencinin kendini ifade edemediği durumlarda anadil kullanabileceği görüşlerini belirtmişlerdir.

İngilizce derslerinde anadilin ne zaman kullanılması gerektiğine ilişkin İngilizce öğretmenlerinin görüşleri

Katılımcılara “İngilizce derslerinde ana dil ne zaman kullanılmalı veya ne zaman kullanılabilir?” sorusu yöneltilmiş ve katılımcıların cevaplarının içerik analizi yapılarak aşağıdaki tabloda verilmiştir. 
Tablo 3: İngilizce derslerinde anadilin ne zaman kullanılması gerektiğine ilişkin İngilizce öğretmenlerinin görüşleri

\begin{tabular}{|c|c|c|c|}
\hline Öğretmenlerin Görüşleri & Katılımcı kodu & $\mathbf{f}$ & $\%$ \\
\hline Dilbilgisi kurallarını anlatırken kullanılmalı, & $\begin{array}{l}\text { Ö1,Ö5,Ö7,Ö9,Ö10,Ö11,Ö13,Ö15,Ö18,Ö } \\
\text { 19, Ö22, Ö23, Ö27, Ö28, Ö29, Ö30, Ö31 }\end{array}$ & 17 & 50 \\
\hline Çeviri çalışmaları yaparken kullanılmalı. & Ö1, Ö2, Ö7, Ö10, Ö21, Ö22, Ö23, & 7 & 20,6 \\
\hline Öğrencinin zorlandığı durumlarda kullanılabilir. & Ö1, Ö3, Ö6, Ö7, Ö20, Ö31 & 6 & 17,6 \\
\hline Kelime öğretiminde kullanılmalı & Ö7, Ö15, Ö26, Ö27, Ö28 & 5 & 14,7 \\
\hline $\begin{array}{l}\text { İlk ve ortaokulda gibi düşük düzeylerde } \\
\text { kullanılabilir. }\end{array}$ & Ö3, Ö10, Ö14, Ö29, & 4 & 11,7 \\
\hline Öğrencinin motivasyonunu artırmak için. & Ö7, Ö10, Ö13, Ö26 & 4 & 11,7 \\
\hline $\begin{array}{l}\text { Tamamen İngilizce kullanıldığında ögrrencilere zor } \\
\text { ve anlamsız gelebiliyor. }\end{array}$ & Ö4, Ö21, Ö27 & 3 & 8,8 \\
\hline Ders anlatımını kolaylaştırmak için kullanılabilir. & Ö18, Ö27 & 2 & 5,8 \\
\hline Zaman kazanmak için kullanılmalıdır. & Ö9, Ö29 & 2 & 5,8 \\
\hline Sınıf yönetimini sağlamak için kullanılmalı, & Ö26 Ö29 & 2 & 5,8 \\
\hline Dersin akıcılığını sağlamak için kullanılabilir. & Ö4 & 1 & 2,9 \\
\hline
\end{tabular}

Tablo 3 incelendiğinde katılımcıların önemli bir kısmının ( $\mathrm{f}=17, \% 50)$ anadilin özellikle dilbilgisi kurallarını anlatırken kullanılması gerektiği yönünde görüş bildirdikleri görülmektedir. İkinci olarak İngilizce öğretmenlerinin çeviri yaparken ana dilin kullanılabileceği yönünde görüş bildirdikleri görülmektedir. Anadilin İngilizce sınıflarında kullanılmasına ilişkin öne çıkan bir başka görüşün ise öğrencilerin zorlandıkları durumlarda anadilin kullanılabileceği yönündeki görüşleridir. İngilizce derslerinde anadil kullanımına ilişkin olarak bazı katılımcıların görüşlerine aşağıda yer verilmiştir;

Öğrenci bilgiyi almakta zorlanırsa almaktan vazgeçebilir (Ö1).

Özel durumlarda, ögrenci kendini yabancı dilde ifade edemiyorsa ana dil kullanmasina müsaade edilebilir. Ya da çeviri yaparken ana dillerini tabi ki kullanmaları gerekir (Ö2).

Bence gerekli olduğunda kullanılmalıdır. Özellikle ilkokul-ortaokul düzeylerinde tamamen yabancı dil kullanımının çok verimli olmadığını düşünüyorum. Anlaşılmadığım bir kitleye sürekli konuşuyor olmak rahatsız edici. Ama gruba ve grup elemanlarına göre yabancı dil kullanımı daha iyi sonuçlar verecektir (Ö3).

Özellikle gramer anlatılırken anadil kullanılmalıdır. Aksi takdirde öğrenci anlayamadı̆̆ı için dersten soğuyacaktır (Ö13).

Ders anlatırken yani dil yapısı bilgileri verirken kullanılmalı. Ĕger kullanilırsan ögrenci anlamakta zorluk çekeceği için dersten kopar ve dile karşı soğukluk yaşar. Ders anlatımını kolaylaştırmak için ana dil kullanılmalı ama mümkün olduğunca yabancı dile yer verilmeli ki ögrenci bilinçaltına işlesin (Ö18).

Öğrencileri güdülemek, sinıf yönetimini să̆lamak, yeni kelimeler öğretmek istenildiğinde anadil kullanılmalıdır. Bu gibi durumlarda kullanılmaz ise ögrenci dersten kopar, bilmediği bir şeye maruz kaldığı için çabuk sıkılır ve dersten soğuyabilir (Ö26).

Dil bilgisi kuralların verirken, dil yapısını anlatırken, yeni kelimeler öğretirken ana dili ve yabancı dili karşılaş̧tırırken anadil kullanılmalıdır. Öğrenci aşina olmadı̆̆ bilgileri alırken zorlanacaktır. Onlara yardımcı olmak ve işlerini kolaylaş̧ırmak için anahtar olarak anadili kullanabiliriz (Ö27).

Gramer konusunu anlatırken ve soruların açıklanması gerektiği durumlarda öğrenci yabancı dilde yaptığım açıklamaları anlamadı̆̆ını ifade ediyor veya dinlemiyor o yüzden anadili kullanmak vakit açısından daha faydalı olabiliyor (Ö29). 
Anadil yabancı dil eğitiminde bu sürecin mutlaka içinde olmalı ve onun ne kadar kullanılacă̆ını ders öğretmeni belirlemeli. Çünkü yabancı dil öğretiminde bazı soyut konular mevzu bahis olduğundan konunun tam anlamiyla olmasa bile öğrenilmesi hususunda vazgeçilmez bir etmendir (Ö31).

Tablo 3 ve devamında yer alan örnek öğretmen görüşleri incelendiğinde bu görüşlerin literatürde yer alan öğretmenlerin anadil kullanma nedenleriyle benzerlik gösterdiği görülmektedir. Atkinson (1987), Macaro (2009) ve Tang (2002) gibi birçok araştırmacı yaptıkları çalışmalarda öğretmenlerin özellikle dilbilgisi kurallarının anlatılması, yönerge verme ve öğrencilerin hatalarını düzeltmede anadili kullanmayı tercih ettiklerini ortaya koymuştur. Bu çalışmada da görüldüğü gibi öğretmenlerin yarısı özellikle dilbilgisi kurallarının anlatılmasında anadil kullanımının konuyu anlaşılır kılmak açısından gerekli bulmaktadır. Anadil yeni kelimelerin öğretilmesinde zaman kazanma, hız ve kolaylık sağladığı için tercih edildiği başka çalışmalarca da desteklenmektedir (Gomathi ve Kiruthika, 20013; Şenel, 2010).

\section{İngilizce derslerinde anadilin ne zaman kullanılmaması gerektiğine ilişkin İngilizce öğretmenlerinin görüşsleri}

Katılımcıların Tablo 2'de vermiş oldukları cevaplarda çoğunluğun anadilin kullanılması gerektiği yönünde görüş bildirdikleri görülmektedir. Katılımcılara "Hangi durumlarda/ne zaman anadil kullanılmamalı?" sorusu yöneltilmiş ve katılımcıların görüşlerinin içerik analizi yapılarak aşağıdaki özet tablo oluşturulmuştur.

Tablo 4: İngilizce derslerinde anadilin ne zaman kullanılmaması gerektiğine ilişkin yabancı dil öğretmenlerinin görüşleri.

\begin{tabular}{|c|c|c|c|}
\hline Öğretmenlerin Görüşleri & Katılımcı kodu & $\mathbf{f}$ & $\%$ \\
\hline Konuşma ve dinleme aktivitelerinde kullanılmamalı. & Ö1,Ö7,Ö12,Ö13,Ö16,Ö19,Ö28,Ö29 & 8 & 23,5 \\
\hline Öğrenci anlamasa bile anlamaya zorlanmalı. & Ö1,Ö8,Ö12,Ö16,Ö21, Ö25 & 6 & 17,6 \\
\hline $\begin{array}{l}\text { Öğrencilerle yabancı dilde anlaşabiliyorsanız Türkçe } \\
\text { kullanmamalısınız. }\end{array}$ & Ö4,Ö9, Ö25 & 3 & 8,8 \\
\hline Yabancı dil bölümü sınıflarında kullanılmamalı. & Ö10, Ö13, Ö23 & 3 & 8,8 \\
\hline Jest ve mimiklerimizle anlamalarına yardımcı olabiliriz. & Ö1, Ö8, & 2 & 5,8 \\
\hline Öğrenciler derse katılırken İngilizce kullanmalılar. & $\ddot{\mathrm{O}} 2$ & 1 & 2,9 \\
\hline $\begin{array}{l}\text { Derse katılırken İngilizce kullanmak pratiği artırır ve dile } \\
\text { yatkınlık gelişir. }\end{array}$ & Ö2 & 1 & 2,9 \\
\hline Dört dil becerisinde kullanılmamalıdır. & Ö29 & & \\
\hline Bence hiç kullanılmamalı. & Ö5 & 1 & 2,9 \\
\hline
\end{tabular}

Yukarıda yer alan Tablo 4 incelendiğinde öğretmenlerin anadilin "konuşma ve dinleme aktivitelerinde" kullanılmaması gerektiği yönündeki görüşlerinin birinci sırada yer aldığı görülmektedir. Konuya ilişkin olarak Ö1 kodlu katılımcı "Konuşma, dinleme aktivitelerinde kullanılmamalıdır. Öğrenci anlamazsa bile anlamaya zorlanmalıdır. Jest ve mimiklerle anlatmak istediğimiz duyguyu verip anlamalarına yardımcı olmalıyız" şeklinde ifade ettiği düşünceler ile beden dilinin kullanılmasının konuşma ve dinleme aktivitelerine yardımcı olabileceği düşüncesini vurgulamıştır. Tabloda yer alan ikinci görüşe göre ise öğrenciler anlamasa bile onları zorlamak gerektiği belirtilmektedir. Öğrencilerin kendilerini İngilizce konuşmak zorunda hissetmeleri kolay yolu seçip anadili kullanmaktansa, İngilizce kendilerini ifade etmeye çalışarak aslında yabancı dillerini pratik etmelerinin sağlanabileceği belirtilmektedir. Üçüncü olarak öğrencilerle İngilizce de anlaşabilmek bir kriter olarak öne sürülmektedir. Öğrencilerle İngilizce anlaşabilen bir öğretmenin anadili kullanmaması gerektiği belirtilmektedir. İngilizce öğretmenlerinin ne zaman anadil kullanmamaları gerektiğine ilişkin bazı ifadelere aşağıda yer verilmiştir;

Dinleme ve konuşmada mümkün olduğunca anadil kullanılmamalı öğrenci hedef dile aşina edilmeli (Ö7).

Çocuğu dile aşina etmek ve dili öğrenme ihtiyacı oluşturmak için anadil kullanılmamalı (Ö11).

Anadil kullanılmamalı. Bir dil ile başka bir dil öğretilemez (Ö15) 
Çok gerekli olduğu durumlar dışında kullanılmamalı. Tam bir dil hakimiyeti sağlamak için İngilizce düşünen bir grup oluşturmak şart (Ö20) .

Öğrencilere bilgi yüklemesi yaparken anadil kullanılmalıdır. Bir şeyler öğrenmek yeterince zor ve sıkıcı iken onların zorluğunu ikiye katlamak doğru değil (Ö28).

Dil sinıflarında kesinlikle anadil kullanılmamalıdır. Çünkü dil öğrenmekten ziyade edinilir. Edinmek ise maruz kalarak gerçekleşir. Tipkı yeni doğan bir bebeğin hiçbir şey bilmez iken 7 ay gibi kısa bir sürede dile küçük tepkiler vermesi ve 1 yll gibi bir sürede ise dili anlayıp karşıllı vermesi gibi. Öğrencileri yeni dile ne kadar maruz bırakırsak o kadar çabuk verim elde ederiz. İlk başlarda zorlansak da meyveleri daha çabuk toplamak için buna değer (Ö34).

Yukarıdaki ifadelerden de anlaşıldığı gibi İngilizce derslerinde anadil kullanımının minimize edilmesi, öğrencilerin yabancı dildeki konulara, telaffuza aşina olmaları, yeni kelime ve konuları pratik yapma firsatı sunması nedeniyle önemsenmektedir. Anadil ortamında öğrencilerin öğrenilen konuları pratik yapmaları ders saatleri dışında çok zor olduğundan derslerde İngilizce kullanımının daha da gerekli olduğu söylenebilir.

\section{SONUÇ VE ÖNERILLER}

İngilizce öğretimi konusunda farklı kesimler farklı yorumlarda bulunmakla birlikte, genelde başarısız veya yetersiz olduğumuz yönünde görüşler sıkça görülmektedir. İngilizce öğreniminde başarı tek bir olguya değil, onlarca belki daha fazla olgu ve sürecin etkileşimi ile ilgilidir. Bunların bazıları öğretmenin kullandığı öğretim metodu, materyal, sınıf düzeni, öğrencinin motivasyonu, öğrenme ortamının 1sı, aydınlatma gibi ergonomik koşulları saymak mümkündür. Öğretmenin sınıfta anadili kullanması da yine önemli tartışma konularından birisi olarak süre gelmiştir. Konuya ilişkin olarak literatür farklılık görüşlere yer vermektedir. Ancak bu çalışmada, katılımcıların önemli bir çoğunluğu $(\% 61,7)$ anadilin kullanılması gerektiği yönünde görüş bildirmişlerdir.

Al-balawi (2016, s. 58) anadili öğretmenlerin \%80 oranında kullandıklarını, yabancı dili nadiren kullandıklarını ifade etmiştir. Polia ve Duff (Akt. Edstrom, 2006, s. 13) da yabancı dil öğretmenlerinin çoğunluğunun anadili ve ikinci dili ne kadar ve niçin kullandıklarının farkında olmadıklarını belirmiştir. Bazı araştırmacılar (Kahraman, 2009; Macaro, 2009; Paker ve Karaağaç, 2015; Schweers, 1999; Tang, 2002) yabancı dil öğretiminde anadilin kullanılmasın gerektiğini, bunun kaçınılmaz olduğunu belirtirken, hedef dildeki becerilerin gelişmesini sağlamak için anadilin kullanılmaması gerektiği yönünde görüş bildirenler de engelleyebileceğini savunanlarda (Kayaoğlu, Öztürk ve Dağ Akbaş, 2010; Krashen, 1982; Sarıçoban, 2010, Turnbull, 2001) bulunmaktadır. Yabancı dil öğretiminde öğrencilerin hedef dile mümkün olduğu kadar fazla maruz kalmaları dil becerilerinin gelişimi açısından önemlidir. Ancak ortak bir anadilin olması İngilizce öğretiminde bazı kolaylıklar sağlayabilir, kelime öğretimi veya dilbilgisi kurallarının anlaşılırlığını artırmak için benzer örnekler anadilde de verilebilir.

Anadilin dil sınıflarında ne zaman kullanılması gerektiğine ilişkin katılımcıların yarısı $(f=17, \% 50)$ dilbilgisi kurallarının öğretiminde anadilin kullanılabileceği görüşünü paylamışlardır. Diğer görüşlerin ise çeviri yaparken, öğrenciler zorlandığı zaman ve kelime öğretimi esnasında anadilin kullanabileceği yönünde yoğunlaştığı görülmüştür. Benzer görüşlere literatürde de rastlanmaktadır. Buckmaster (2000) ve Cole (1988) soyut kelimelerin açıklanmasında, anadil ile yabancı dil arasındaki dilbilgisi ve telaffuz farklılıklarını ortaya koyma açısından anadil kullanımının büyük kolaylık sağladığını ifade etmişlerdir. Auerbach (1993) ise anadilin rahat bir öğrenme ortamı oluşturduğunu ifade etmiştir.

Anadilin hangi durumlarda kullanılmaması gerektiğine ilişkin olarak katılımcılar, ilk olarak $(\mathrm{f}=8, \% 23,5)$ konuşma ve dinleme becerilerinde kullanılmaması gerektiği yönünde görüş ifade etmişlerdir. Konuşma ve dinleme becerileri öğrencilerin yabancı dilde pratik yapmalarıyla doğru orantılı olarak gelişebilecek becerilerdir. Halliwell ve Jones (1993) hem konuşmada hem de konuşulanın anlaşılmasında İngilizce kullanılmasının bir strateji olarak kelime ve yapıların tam anlamlarını bilmeseler bile öğrencilerin mesajı anlamalarına yardımcı olacağını ifade etmişlerdir. İngiltere Eğitim Standartları Ofisi (OFSTED,1993, s. 37) müfettiş kılavuzunda öğretmenlerinin hedef dili kullanmada 1srarlı olmaları gerektiğini bunun standartları yükseltmek için gerektiğini ifade etmektedir. Bu nedenle İngilizce dil sınıflarında özellikle çocuklarda konuşma ve dinleme becerilerinin gelişimi açısından anadil kullanımının azaltılmasının 
önemli olduğunu vurgulamakta yarar var. Dilin doğal kullanımının konuşma ve konuşulanları anlamak, yani dinlemek şeklinde olduğunu unutmamak gerekir.

Öğretmenler için öneriler;

1. İngilizce öğretmenlerinin çoğunluğunun anadil kullanılması gerektiği yönünde görüş bildirdikleri görülmektedir. Ancak öğretmenlerin önemli bir kısmının da anadil kullanılmasına karşı çıktığ1 görülmektedir. Literatürde yer alan bulgularda göz ardı etmeden anadil kullanımını özellikle dersi öğrencilere sevdirmek ve dil öğrenme korkusunun oluşmaması için başlangıç düzeyinde İngilizce derslerinde anadilden faydalanılması önerilir.

2. Dil öğrenmek bir süreçtir ve bu süreçte anadilin kullanılması her ne kadar doğal ve bazı konuların anlatımı açısından süreci hızlandırıcı bir etki olarak kabul edilse bile, İngilizcenin öğretildiği dil sınıflarında öğrencilerin öğretilen dile daha fazla maruz kalmasını sağlamak için anadil kullanımını minimize etmek başlangıç düzeyi hariç, orta ve ileri düzeylerde İngilizce öğretilirken bir zorunluluk haline getirilmelidir. Öğrencinin dili uygulama ve kullanma konusunda sınıf ortamının dışında olanağa sahip olmadığı bu gibi durumlarda sınıf ortamını bu eksikliği gidermek için kullanmak faydalı olacaktır. Yapılan çalışmaların bir çoğu ikinci yabancı dil olarak İngilizce öğretimi gibi durumlarda yapıldığından, sınıf dışında öğrencinin öğrendiği dili kullanması zaten bir zorunluluk olacağından, sınıfta ana dil kullanımı belki kelime öğretimi, dil kurallarının anlatımı gibi durumlarda süreci hızlandırıcı ve öğrencilerin anlamasına faydalı etkiye sahip olabilir.

3. Öğrencilerin daha rahat hissettikleri için anadili kullanmayı tercih etmektedirler ancak İngilizce öğretmenlerinin anadil kullanımını azaltmak için öğrencileri motive etmeleri gerekebilir. Onların kaygılarını anlamalı, yanlış yapma veya küçük düşürülme gibi olumsuz dönüt beklentileri giderilmeli ve öğrencilerin hataları seviyelerine uygun, kırıcı olmayan daha çok dile odaklanan olumlu bir dil kullanılarak düzeltilmeye çalışılmalı. Özellikle alt düzeylerde dil seviyesine sahip öğrencilerde dilde akıcıllğı sağlamak ve hatalara odaklanmayı azaltmak için düzeltme yapmama veya hataları düzeltmeyi erteleme tercih edilebilir, bu düzeyde yer yer anadil kullanılabilir.

4. Yabancı dil gelişimi açısından anadilin kullanılmasının minimize edilmesi gerektiği yapılan çalışmalarca da ortaya konmuştur. Öğretmenlerin anadil kullanımını azaltmak için daha fazla eğitici ders materyalinden, görsel öğelerden yararlanmaları ve materyal geliştirmeye daha fazla vakit ayırmaları gerekir. Anadil kullanmak yerine görsel materyallerle öğrencilerin kavrama yeteneğini geliştirmelerine yardımcı olunabilir.

İngilizce dil eğitimi konusunda yapılan binlerce çalışma olmasına rağmen benzer çalışmaların her zaman yapılmasında yarar görülmektedir. Bu yapılan çalışmaları bir doğrulaması olabildiği gibi aynı zamanda değişen şartlar doğrultusunda duruma özgü gelişmeleri takip etmek açısından önemlidir. Eğitim teknolojilerinin önemli ilerleme sağladığı bu günlerde yabancı dil öğretimi konusunda bu materyallerin etkililiği ve dil öğrenme ortamına katkılarını irdeleyici çalışmalar yapılabilir. Farklı dil ortamlarında anadil kullanımına ilişkin karşılaştırmalı çalışmalar yapılabilir.

\section{KAYNAKÇA}

Al-balawi, F.S.(2016). The attitudes of Saudi EFL teachers about using their mother tongue in EFL classrooms. International Journal of Education and Social Science 3 (7), 51-61.

Al-Hinai, M. K. (2006). The use of the L1 in the elementary classroom. In S. Borg (Ed.). Classroom research in English language teaching in Oman. Muscat: Ministry of Education, Sultanate of Oman.

Al-nofaie, H. (2001). The attitudes of teachers and students towards using Arabic in EFL classrooms in Saudi public schools: a case study', in Novitas-Royal (Research on youth and language), 4(1), 64-95.

Atkinson, D. (1987). The mother tongue in the classroom: A neglected resource? ELT Journal, 41(4), 241-247. 
Auerbach, E. (1993). Re-examining English only in the ESL classroom. TESOL Quarterly, 27(1), 9-32.

Buckmaster, R. (2000) First and second languages do battle for the classroom. 20 Nisan 2019 tarihinde https://www.theguardian.com/education/2000/jun/22/tefl3 adresinden erişildi.

Butzkamm, W. (2003). We only learn language once. The role of the mother tongue in FLclassrooms: death of a dogma. Language Learning Journal, 28, 29-39.

Chambers, F. (1991). Promating use of the target language in the classroom. Language Learning Journal, 4, 27-31.

Carson, E. \& Kashihara, H. (2012). Using the L1 in the L2 classroom: The students speak. The Language Teacher Online, 36(4), 41-52.

Cole, S. (1998) The use of L1 in communicative English classrooms. 19 Nisan 2019 tarihinde http://jaltpublications.org/old_tlt/files/98/dec/cole.html adresinden erişildi.

Cook, V.J. (1999). Going beyond the native speaker in language teaching. TESOL Quarterly, 33(2),185209.

Cook, V.J. (2001). Using first language in the classroom. The Canadian Modern Language Review, 57(3), 402-423

Cresswell, J.W. (2013). Nitel Araştırma Yöntemleri: Beş Yaklaşıma Göre Nitel Araştırma veAraştırma Desenleri (3.Bask1). Ankara: Siyasal Kitapevi.

Çelik, M. (2003). Teaching vocabulary through code-mixing. ELT Journal, 57(4), 361-369.

Department of Education and Science. (1990). Modern foreign languages in the school curriculum: $\quad$ A statement of policy. London: Her Majesty's Stationery Office.

Dodson, C. J. (1967). Language teaching and the bilingual method. London: Pitman.

Duff, A. (1989). Translation. Oxford: Oxford University Press.

Duff, P. A., \& Polio, C. G. (1990). How much foreign language is there in the foreign language classroom? The Modern Language Journal, 74(2), 154-166.

Edstrom, A. (2006). L1 use in the L2 classroom: One teacher's self-evaluation. The Canadian Modern Language Review, 63(2), 275-292.

Faltis, C. (1990). New directions in bilingual research design: The study of interactive decision making. In Jacobson, R. and Faltis, C., ed. Language distribution issues in bilingual schooling. Clevedon: Multilingual matters, 45-57.

Fraenkel, J. R., \& Wallen, N. E. (2006). How to design and evaluate research in education. NewYork: McGraw-Hill.

Gomathb.S. I.\& Kiruthika, P. (2013). Role of L1 in English language teaching to rural area students with reference to erode region. International Journal of Humanities and Social Science Invention, 2(12), 24-26.

Gulzar, M. A. (2010). Code-switching: Awareness about its utility in bilingual classrooms. Bulletin of Education and Research, 32(2), 23-44.

Halliwell, S. and Jones, B.(1991). On target teaching in the target language. London: Centre for Information on Language Teaching and Research.

Harbord, J. (1992). The use of mother tongue in the classroom. ELT Journal, 46(4), 350-55

Harmer, J. (2004). How to teach writing. New York: Pearson Education Limited.

Hawkins, E. (1981). Modern languages in the curriculum. Cambridge: Cambridge University Press.

Holthouse, J. (2006). The role of the mother tongue in EFL classrooms. Forum for Froeign Language Education, 5(03), 27-37. 
Howatt, A. P. R. (2004). A History of English Language Teaching. Oxford: Oxford UniversityPress.

Kahraman, A. (2009). The role of the mother tongue in fostering affective factors in ELTclassrooms. Journal of English as an International Language, 5, 107-128.

Kayaoğlu, M.N. (2012). The use of mother tongue in foreign language teaching from teachers' practice and perspective. Pamukkale Üniversitesi Eğitim Fakültesi Dergisi, 32(2), 25-35.

Kayaoğlu, M. N., Öztürk, Z.\& Dağ Akbaş, R. (2010). L1 use in EFL classroom: The attitudesof students. Dinçay, K., Erten, İ. H., ZehirTopkaya, E., \&Yavuz, A. (Eds.) The $6^{\text {th }}$ International $\quad$ ELT Research Conference Proceedings: Current trends in SLA research and language teaching (pp. 401-407). Selçuk, İzmir: Çanakkale Onsekiz Mart University.

Kelly, L. (1969). 25 Centuries of language teaching: 500BC-1969. Rowley, Mass: NewburyHouse.

Koucka, A. (2007). The role of mother tongue in English language teaching. University of Pardubice, Faculty of Arts and Philosophy, Department of English and American Studies.

Krashen, S. (1982). Principles and practice in second language acquisition. Oxford: Pergamon

Krashen, S. D., \& Terrell, T. D. (1983). The Natural Approach: Language Acquisition in the classroom. Englewood Cliffs, New Jersey: Prentice Hall

Larsen-Freeman, Diane. 1986. Techniques and Principles in Language Teaching. Oxford University Press.

Larsen-Freeman, D. (2000). Techniques and principles in language teaching. Oxford: Oxford University Press.

Lasagabaster, D. (2013). The use of the L1 in CLIL classes: The teachers' perspective. Latin American Journal of Content and Language Integrated Learning, 6(2), 1-21.

Long, M. (1981). Input, interaction and second language acquisition. In H. Winitz (Ed.), Native language and foreign language ac- quisition (259-278). Annals of the New YorkAcademy of Sciences 379. New York: Academy of Sciences.

Macaro, E. (2009). Analysing student teachers' codeswitching in foreign language classrooms:Theories and decision making. Modern Language Journal, 85, 531-548.

Macdonald, C.(1993). Using the target language. Cheltenham: Mary Glasgow. Ministry of Education, 1974. The educational policy in the Saudi Arabian Kingdom. 2. ed. Riyadh: Ministry of education.

Mahmutoğlu, H. ve Kıcır, Z. (2013). The use of mother tongue in EFL classrooms. EUL Journal Social Sciences 4(1), 49-72.

Mattioli, G. (2004). On native language intrusions and making do with words: Linguistically homogenous classrooms and native language use. English Teaching Forum, 2(43), 20-25.

Meyer, H. (2008). The pedagogical implications of L1 use in the L2 classroom. Maebashi Kyodai Gakuen College Ronsyu, 8, 147-159.

Miles, M. B. \& Huberman, A. M. (1994). Qualitative data analysis. London: Sage Publication.

Moghadam, S. H., Samad, A. A., \& Shahraki, E. R. (2012). Code switching as a medium ofinstruction in an EFL classroom. Theory and Practice in Language Studies, 2(11), 2219-2225.

Moss, Donna. 2005. Teaching for communicative competence. focus on basics. Connecting Research and Practice Magazine. 20 Nisan 2019 tarihinde http://www.ncsall.net/fileadmin/resources/fob/2005/fob_7c.pdf adresinden erişildi.

Mulia, D. (2012). The use of first language scaffolding to teach English as a foreign language to preschool children during dramatic play in West Sumatera, Indonesia. SHS Web of Conferences 16, EDP Sciences DOI: 10.1051/shsconf/20151601005, 
Nation, P. (2003). The role of the first language in foreign language learning. The Asian EFL Journal, 5 (2).

Neil, P.S. (1997). Reflections on the target language. London: Centre for Information on Language Teaching.

Norman, J. (2008). Benefits and drawbacks to L1 use in the L2 classroom. In K. Bradford Watts, T. Muller \& M. Swanson (Eds.), JALT 2007 Conference Proceedings. Challenging Assumptions: Looking In, Looking Out, (691-701). Tokyo: JALT.

Nunan, David. 1989. Designing tasks for the communicative classroom. Cambridge University Press

Ocak, G., Kuru, N., \& Ozcalisan, H. (2010). As a classroom language, students' attitudes towards speaking Turkish in English prep classes. Procedia Social and Behavioral Sciences 2, 661-665.

Ofiice for Standarts in Education. (1993). Handbook: Inpection schedule. London: Her Majesty's Stationery Office

Parker, T. \& Karaağaç, Ö. (2015). The use of functions of mother tongue in EFL classes. ProcediaSocial and Behavioral Sciences 199, 11-119. 8 Nisan 2019 tarihinde https://www.sciencedirect.com adresinden erişildi.

Polio, C. G., \& Duff, P. A. (1994). Teachers' language use in university foreign language classrooms. The Modern Language Journal, 78(3), 313-326.

Ramos, F. (2005). Spanish teachers' opinions about the use of Spanish in main stream English classrooms before and after their first year in California. Bilingual Research Journal, 29(2), 411433.

Richards, J. C. \& Rodgers, T. S.. 2005. Approaches and methods in language teaching.UK: Cambridge University Press.

Samadi, M. R. (2011), Role of The L1 in FL classrooms: Learner and teacher beliefs, attitudes and practices. Unpublished Master's Thesis, Kansas State University, USA.

Sarıçoban, A. (2010). Should native languages be allowed in foreign language classes? Eurasian Journal of Educational Research, 38, 164-178.

Schweers, C.W. Jr. (1999). Using L1 in the L2 classroom. English Teaching Forum, 37(2), 6-9.

Sharma, K. (2006). Mother tongue use in English classroom. Journal of NELTA, 11(1-2), 80-87.

Simon, M. K.ve Goes, J. (2011). What is phenomenological research? Seattle, WA: Dissertation Success LLC. 25 Nisan 2019 tarihinde https://www.google.com.tr/url?sa=t\&rct= j\&q=\&esrc= s\&source=web\&cd=2\&cd=rj\&uact=8\&ved=0ahUKEwip5a39tjKAhXD2SwKHR7BToQFggtM AE\&url=http\%3A\%2F\%2Fdissertationrecipes.com\%2Fwpcontent\%Fuploads\%2 F2011 \%2F04\%2FPhenomenologicalResearch.pdf\&usg=AFQjCNEJbQJnMQxjvZshGr_S65I15eeo0w adresinden erişildi.

Sipra, M. A. (2007). Bilingualism as teaching aid in a language class: L1 as a facilitator inteaching/ learning process of L2 at intermediate/certificate level. Unpublished doctoral dissertation, National University of Modern Languages, Islamabad.

Soleimani, H. \& Heidarikia, H. (2017). The effect of translation as a noticing strategy on learning complex grammatical structures by EFL learners. Applied Linguisics Research Journal, 1(1), 112.

Stapa, S. H.,\& Majid, A. H. A. (2009). The use of first language in developing ideas in second language writing. European Journal of Social Sciences, 7(4), 41-47.

Stern, H.H. (1992). Issues and options in language teaching. Oxford: Oxford University Press.

Storch, N. \& Wigglesworth, G. (2003). Is there a role for the use of the L1 in an L2 setting? TESOL Quarterly 37(4), 760-770. 
Şahin, M., Korkmaz, C. \& Üstüner, M. (2018). İngilizce öğretmenlerine göre ideal dil öğrenme yaşı ve dil sinifi mevcudu. International Journal of Language Academy, 6(2), 281-301.

Şavlı. F. \& Kalafat, S. (2014). Yabancı dil derslerinde ana dili kullanımı üzerine öğretmen ve öğrenci görüşleri. Turkish Studies, 9(3), 1367-1385.

Şenel, M. (2010). Should foreign language teaching be supported by mother tongue? Journal of Language and Linguistic Studies, 6(1), 110-120.

Tang, J. (2002). Using L1 in the English classroom. English Teaching Forum, 40(1), 36-43.

Turnbull, M. (2001). There is a role for the L1 in second and foreign language teaching, but... The Canadian Modern Language Review, 57(4), 531-540.

VanPatten, B. (Ed.). (2004). Processing instruction. Mahwah, NJ: Erlbaum.

Willis, J. 1991. Teaching English through English. Harlow: Longman.

Wing, B.H. (1980). The languages of the foreign language classroom: A study of the native and target languages for linguistic functions. Unpublished doctoral dissertation, University of Michigan, Ann Arbor, USA. 